\title{
Histology of tissues and cell wall of rice straw influenced by treatment with different chemicals and rumen degradation*
}

\author{
D. Liu ${ }^{1}$, J.X. Liu ${ }^{1,3}$, S.L. Zhu ${ }^{1}$, X.J. Chen ${ }^{2}$ and Y.M. Wu ${ }^{1}$ \\ ${ }^{1}$ Zhejiang University, College of Animal Sciences \\ Hangzhou 310029, P.R. China \\ ${ }^{2}$ Hangzhou Teachers College, School of Life Science \\ Hangzhou 310012, P.R. China
}

(Received 28 September 2004; revised version 16 February 2005; accepted 18 March 2005)

\begin{abstract}
Rice straw (RS) was treated with urea, ammonium bicarbonate $\left(\mathrm{NH}_{4} \mathrm{HCO}_{3}\right)$ and sodium hydroxide $(\mathrm{NaOH})$, respectively. Treatments with urea, $\mathrm{NH}_{4} \mathrm{HCO}_{3}$ and $\mathrm{NaOH}$ increased the in sacco dry matter degradability of RS from 45.3 (untreated) to 52.5, 53.2 and $63.6 \%$, respectively $(\mathrm{P}<0.01)$. The untreated and treated RS stem samples were digested in the rumen of a Huzhou sheep for 12, 24, 48 and $72 \mathrm{~h}$ and examined for the degradation of tissues and cell walls by using a scanning electron microscope (SEM), and a transmission electron microscope (TEM). Parenchyma was slightly distorted by treatment with urea or $\mathrm{NH}_{4} \mathrm{HCO}_{3}$, but severely distorted by $\mathrm{NaOH}$ treatment. The chemical treatments had little effect on other tissues of RS stem. All three treatments accelerated the degradation of parenchyma at 12 and $24 \mathrm{~h}$, and $\mathrm{NaOH}$ treatment made the parenchyma degraded to most extent. Sclerenchyma cell wall in the untreated RS was slightly digested and still left partial secondary wall and complete middle lamella and primary wall even at $72 \mathrm{~h}$, but $\mathrm{NaOH}$-treated sclerenchyma cell wall began to be degraded at $48 \mathrm{~h}$ and just left the middle lamella and occasional primary wall at $72 \mathrm{~h}$. All three treatments made the phloem absent at $48 \mathrm{~h}$, but had little effect on the digestion of epidermis and xylem of vascular tissue. These results indicated that $\mathrm{NaOH}$ treatment had the best effects on the modification of structure of rice straw stems and the digestion of tissues and cell wall, and that the positive effects of $\mathrm{NH}_{4} \mathrm{HCO}_{3}$ treatment basically paralleled those of urea treatment. The improvement in digestion of histological structures was accordant entirely with the increase of in sacco degradability of RS after the three treatments. It is suggested that the histological methods by means of microscopical techniques such as SEM and TEM are conducive to a direct insight into the mechanism with which chemical treatments exerted the effects on the improvement of nutritive value of RS.
\end{abstract}

KEY WORDS: chemical treatment, rice straw, tissue, cell wall, electron microscopy, degradability

\footnotetext{
* Supported by the National Natural Science Foundation of China, No.30270943

${ }^{3}$ Corresponding author: e-mail: liujx@zju.edu.cn
} 


\section{INTRODUCTION}

Rice straw (RS) is the largest by-product of the cereal crops in China, annual yield of which totals currently about $188 \times 10^{6}$ tonnes (Guo et al., 2002), and thus presents a great potential as a useful source of feed for ruminants. However, as feed, RS is poor in palatability and digestibility and is low in nitrogen content (Givens and Angela, 1995; Liu, 1995). Utilization of cell wall constituents of crop residues by rumen microbes is hindered by the presence of nonpolysaccharide compounds such as lignin, phenolic acids and silica in some cereal straws (Besle et al., 1994). Physical, chemical and biological treatments have been used for decades in upgrading and utilizing RS efficiently, and treatment with alkali compounds or ammonia is widely applied as the most successful chemical method (Liu et al., 1997; Chaudhry, 1998). Effects of chemical treatments on intake and digestibility of RS have been studied extensively, but the mechanism with which treatments improve the nutritive value of RS keeps unclear. Knowledge about changes in the histology of RS may help understand how different fractions, tissues and cell wall respond to chemical treatments (Xu et al., 1993; Shen et al., 1999).

Structural methods offer effective ways to evaluate digestion of specific cell types and have increased the understanding of the contribution of plant and rumen microbial factors in digestion of forages (Akin, 1989). In the present study, scanning electron microscope (SEM) and transmission electron microscopy (TEM) were used to observe histological changes of stem related to different chemical treatments before and after digestion in the rumen and to compare the effects of different treatments on degradation of RS structure.

\section{MATERIAL AND METHODS}

\section{Plant material and its treatment}

Rice (Japonica) straw, collected from Zhejiang University Experimental Farm (China) immediately after the rice harvest, was chopped to $3-5 \mathrm{~cm}$, and treated with sodium hydroxide $(\mathrm{NaOH}, 4 \%$ of straw $\mathrm{DM}$, w/w) for two days, urea $(5 \%$ of straw DM, w/w) and ammonium bicarbonate $\left(\mathrm{NH}_{4} \mathrm{HCO}_{3}, 10 \%\right.$ of straw DM, $\mathrm{w} / \mathrm{w}$ ) for 10 days in an airtight thermostated container $\left(35^{\circ} \mathrm{C}\right)$, respectively (Liu et al., 1997). Before pretreatment, moisture content of the RS was adjusted to about $40 \%$. Untreated RS was used as control. 
Measurement of chemical composition and in sacco degradability of rice straw

Untreated and treated RS were ground to pass a $1 \mathrm{~mm}$ sieve. The nitrogen content was determined according to AOAC (1990), and neutral detergent fibre (NDF) following the procedures by Van Soest et al. (1991), respectively. The in sacco procedure as described by Ørskov et al. (1980), was applied to determine the degradability of untreated and treated RS. About $3 \mathrm{~g}$ of samples were weighed into nylon bags ( $40 \mu \mathrm{m}$ mesh, $7 \mathrm{~cm} \times 10 \mathrm{~cm}$ inner size $)$ and suspended in the rumen of three Huzhou sheep for $24 \mathrm{~h}$. The sheep were fed twice daily on a diet containing $60 \%$ hay and $40 \%$ concentrate mixture. Upon removal from the rumen, the bags were immersed in cold water, gently washed by hand for $20 \mathrm{~min}$, and then dried at $60^{\circ} \mathrm{C}$ for $48 \mathrm{~h}$. For estimation of $0 \mathrm{~h}$ values, an additional set of bags was incubated in water at $39^{\circ} \mathrm{C}$ for $1 \mathrm{~h}$, and washed as above.

\section{Preparation of samples for microscopy}

Digestion of plant material. The RS was separated into four parts: node, stem, blade and sheath. Stem materials were used for microscopy. Representative stem samples from untreated and treated materials were selected, cut in length of $5 \mathrm{~mm}$, placed in nylon bags and then subjected to in sacco digestion in a rumen fistulated Huzhou sheep for 12, 24, 48 and $72 \mathrm{~h}$, respectively. At the end of digestion, bags were gently washed by hand in cold water, and then the samples were immediately prepared for electron microscopy observation.

Scanning electron microscopy (SEM). Both undigested and digested stems were cut into small pieces $(1 \mathrm{~mm} \times 3 \mathrm{~mm})$; then fixed in $0.1 \mathrm{~mol} / \mathrm{L}$ phosphate buffer (pH 7.2) containing $2 \%(\mathrm{~V} / \mathrm{V})$ para formaldehyde and $2.5 \%(\mathrm{~V} / \mathrm{V})$ glutaradehyde for $2 \mathrm{~h}$ at $4{ }^{\circ} \mathrm{C}$; rinsed three times in the same buffer; fixed with $1 \%$ osmic acid; rinsed three times in the same buffer; dehydrated in 70, 80, 90, 95 and $100 \%$ $(\mathrm{V} / \mathrm{V})$ ethanol, respectively; treated with a mixed solution of isoamyl acetate and ethanol $(1: 1, \mathrm{v} / \mathrm{v})$ and with $100 \%$ isoamyl acetate; followed by "critical point dry procedure"; coated with platinum under vacuum (JEE-4X, JEOL Ltd., Japan), and finally observed with SEM (KYKY-1000B, KYKY Technology Development Ltd., China).

Transmission electron microscopy (TEM). Both undigested and digested stems were cut into small pieces $(3 \mathrm{~mm} \times 1 \mathrm{~mm})$ and then treated with the same steps as above before being treated with a mixed solution of isoamyl acetate and ethanol. After dehydrating, these pieces were embedded at $-20^{\circ} \mathrm{C}$ in Lowicryl $\mathrm{K}_{4} \mathrm{M}$ according to the following procedure: $100 \%$ ethanol/resin $(1: 1, \mathrm{~V} / \mathrm{V})$ for $1 \mathrm{~h}, 100 \%$ ethanol/resin $(1: 2, \mathrm{~V} / \mathrm{V})$ for $1 \mathrm{~h}$, pure resin for $1 \mathrm{~h}$ and then overnight. Samples were transferred to tubes filled with resin and polymerized under UV light for 
$72 \mathrm{~h}$ at $-20^{\circ} \mathrm{C}$, then for $24 \mathrm{~h}$ at room temperature. The blocks were sectioned on an ultra-microtome (Reichert-Jung ULTRACUT E). Ultra-thin sections were placed on nickel slot grids, and then viewed in TEM (Model JEM-1200EX, JEOL. Ltd., Japan).

\section{RESULTS}

Chemical composition and in sacco degradability of rice straw. Table 1 presents the chemical composition and in sacco degradability of RS at $24 \mathrm{~h}$. The nitrogen content was increased due to treatments with urea and $\mathrm{NH}_{4} \mathrm{HCO}_{3}$, but not influenced by $\mathrm{NaOH}$ treatment. Values for NDF were reduced by $\mathrm{NaOH}$ and urea treatments, but showed little response to $\mathrm{NH}_{4} \mathrm{HCO}_{3}$ treatment. In sacco degradability of dry matter of RS showed a great difference between the untreated and treated RS. The degradability was the highest for $\mathrm{NaOH}$-treated RS $(\mathrm{P}<0.01)$, followed by urea- and $\mathrm{NH}_{4} \mathrm{HCO}_{3}$-treated $(\mathrm{P}<0.01)$ and the lowest for untreated straw.

TABLE 1

Chemical composition and in sacco degradability of dry matter of rice straw

\begin{tabular}{lccccc}
\hline \multirow{2}{*}{ Indices } & \multicolumn{4}{c}{ Rice straw treated by } & \multirow{2}{*}{ SEM } \\
\cline { 2 - 5 } & None & $\mathrm{NaOH}$ & Urea & $\mathrm{NH}_{4} \mathrm{HCO}_{3}$ & \\
\hline Dry matter, g kg-1 & 950 & 933 & 933 & 938 & - \\
Nitrogen, $\mathrm{g} \mathrm{kg}^{-1} \mathrm{DM}$ & 17 & 16 & 28 & 23 & - \\
Neutral detergent fibre, g kg-1 DM & 700 & 664 & 683 & 698 & - \\
In sacco 24 h DM degradability, $\%$ & $45.3^{\mathrm{C}}$ & $63.6^{\mathrm{A}}$ & $52.5^{\mathrm{B}}$ & $53.2^{\mathrm{B}}$ & 0.86 \\
\hline A,B,C & means with different letters within the same row differ significantly $(\mathrm{P}<0.01)$ &
\end{tabular}

Evaluation of stem tissues degradation by SEM. Histological changes of RS stem after different chemical treatments are shown in Figure 1. Intact epidermis, parenchyma, sclerenchyma and vascular bundles were clearly observed in the untreated stem, and vascular bundles included large and small bundles located in parenchyma and sclerenchyma, respectively (Figure 1A). The parenchyma in $\mathrm{NaOH}$-treated stem was so distorted that there were only rudiments left for parenchyma (Figure 1B). Treatments with urea and $\mathrm{NH}_{4} \mathrm{HCO}_{3}$ resulted in a moderate and slight distortion of parenchyma, respectively (Figures $1 \mathrm{C}$ and $1 \mathrm{D}$ ). However, neither of the treatments in this study had great effects on other tissues of RS stem before rumen digestion. 

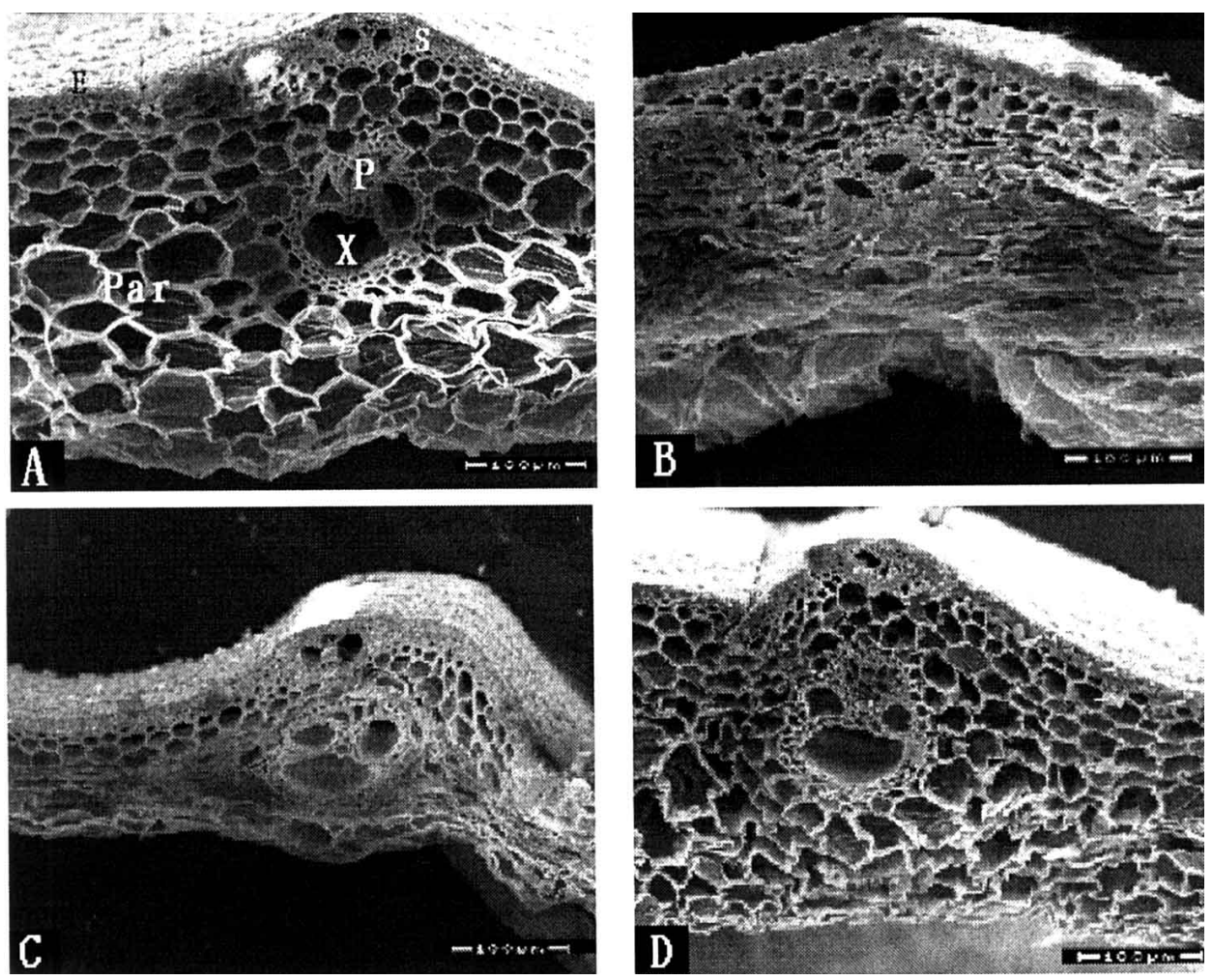

Figure 1. Histological changes of rice straw stem after different treatments. (A) In the untreated stem, epidermis (E), sclerenchyma (S), phloem (P) and xylem (X) of vascular tissue and parenchyma (Par) were intact. (B) $\mathrm{NaOH}$-treated stem, showing that the whole parenchyma was severely collapsed. (C) After treatment with urea, stem parenchyma was moderately distorted. (D) $\mathrm{NH}_{4} \mathrm{HCO}_{3}$-treated stem showing slight distortion of parenchyma $(\mathrm{SEM} \times 200)$

At $24 \mathrm{~h}$ after in sacco degradation, untreated stem still maintained its general structure except for the partial degradation of parenchyma (Figure 2A). $\mathrm{NaOH}$-treated stem showed slight remnants of parenchyma in occasional sites, a great distortion of large vascular bundles and degraded phloem (Figure 2B). In urea- or $\mathrm{NH}_{4} \mathrm{HCO}_{3}$-treated stem, most of parenchyma was degraded, only a little of distorted parenchyma near the sclerenchyma was left and large vascular bundles appeared distorted (Figures 2C and 2D). After $48 \mathrm{~h}$ in sacco degradation, the detectable tissues by SEM were small vascular bundles, epidermis and sclerenchyma, because large vascular bundles had been broken off wholly due to the complete degradation of parenchyma (Figure 3). Untreated stem maintained the integrality of the small vascular bundle (including xylem and phloem), epidermis 

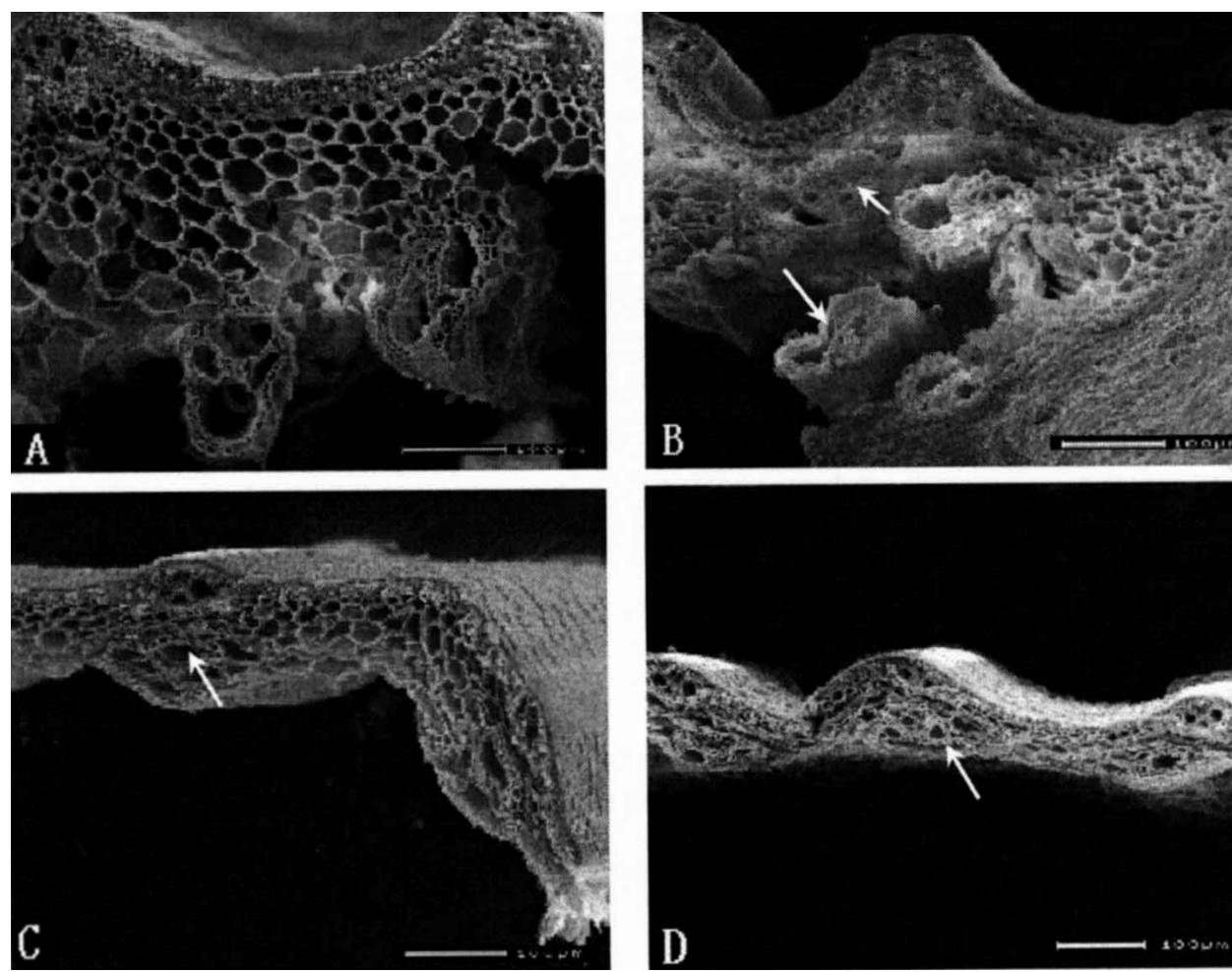

Figure 2. Histological changes of rice straw stem after $24 \mathrm{~h}$ in sacco degradation. In the untreated stem (A), partial parenchyma was degraded. (B) NaOH-treated stem showing slight remnants of parenchyma, slight degradation of phloem and great distortion of large vascular bundles (arrow). In the urea-treated (C) and $\mathrm{NH}_{4} \mathrm{HCO}_{3}$-treated stem (D), only a little of distorted parenchyma nearby sclerenchyma was not degraded and large vascular bundles appeared distorted (arrow) $($ SEM $\times 175)$

and sclerenchyma (Figure 3A). NaOH-treated stem was at the beginning of degradation of sclerenchyma and showed the total loss of phloem, some cracked sclerenchyma cells and intact epidermis (Figure 3B). The phloem was also absent in urea- and $\mathrm{NH}_{4} \mathrm{HCO}_{3}$-treated stems, but sclerenchyma and epidermis still kept indigestible (Figures $3 \mathrm{C}$ and $3 \mathrm{D}$ ).

Evaluation of cell wall degradation by TEM. Cross sections of epidermis, parenchyma, sclerenchyma and vascular bundles were evaluated under TEM for cell wall degradation by rumen microorganisms. Untreated epidermal cells showed the thicker outer cell wall region and the thinner inner cell wall that is adjacent to sclerenchyma. Neither of the cell wall layers of untreated and treated epidermis was digestible, even if they were incubated in the rumen for $72 \mathrm{~h}$. 

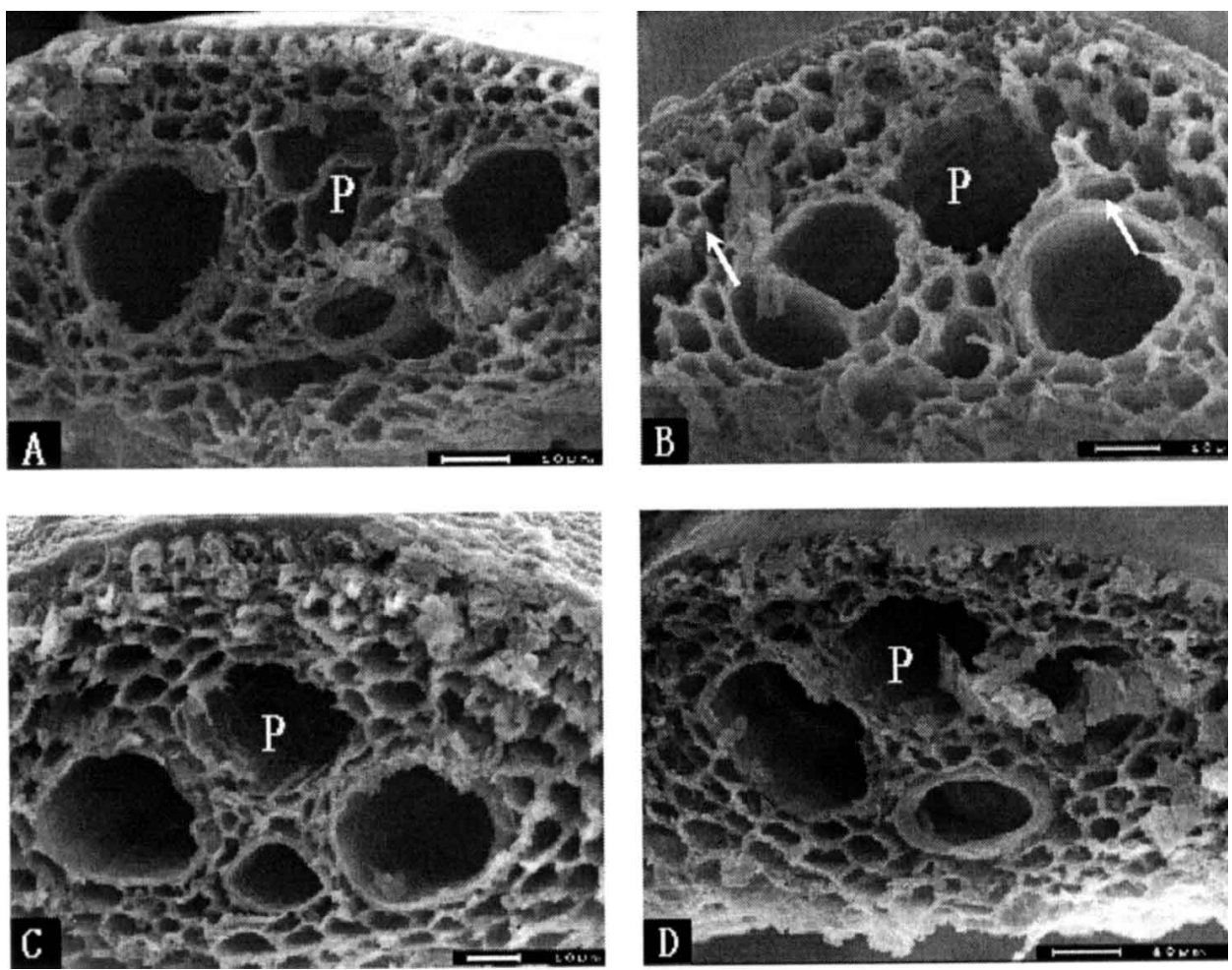

Figure 3. Histological changes of rice straw stem after $48 \mathrm{~h}$ rumen degradation. (A) Untreated stem showing the integrality of epidermis, sclerenchyma, xylem and phloem (P). (B) NaOH-treated stem showing total disappearance of phloem $(\mathrm{P})$, a few cracked sclerenchyma cells (arrow) and intact epidermis. (C) Urea-treated and (D) NH4HCO3-treated stem showing the absence of phloem (P) and the integrality of epidermis, sclerenchyma and xylem $($ SEM $\times 1200)$

Sclerenchyma of undigested and untreated stem showed the thickness and intactness of cell wall (Figure 4A). After $48 \mathrm{~h}$ rumen incubation, the cell wall of $\mathrm{NaOH}$-treated sclerenchyma was colonized by microorganisms, and slight microbial degradation of the secondary wall occurred (Figure 4C), but the degradation was not found in both untreated and other treated sclerenchyma cell walls (Figures 4B and 4D). With further rumen digestion for $72 \mathrm{~h}$, the secondary wall in the untreated sclerenchyma cells was sometimes slightly pitted along its edge (Figure 4E), but there was loss of considerable amounts of the secondary wall in treated sclerenchyma cells. Most of $\mathrm{NaOH}$-treated sclerenchyma cell wall was much thinner than the urea-treated, and the former merely retained the middle lamella and occasional primary wall of cells (Figure 4F), but the 

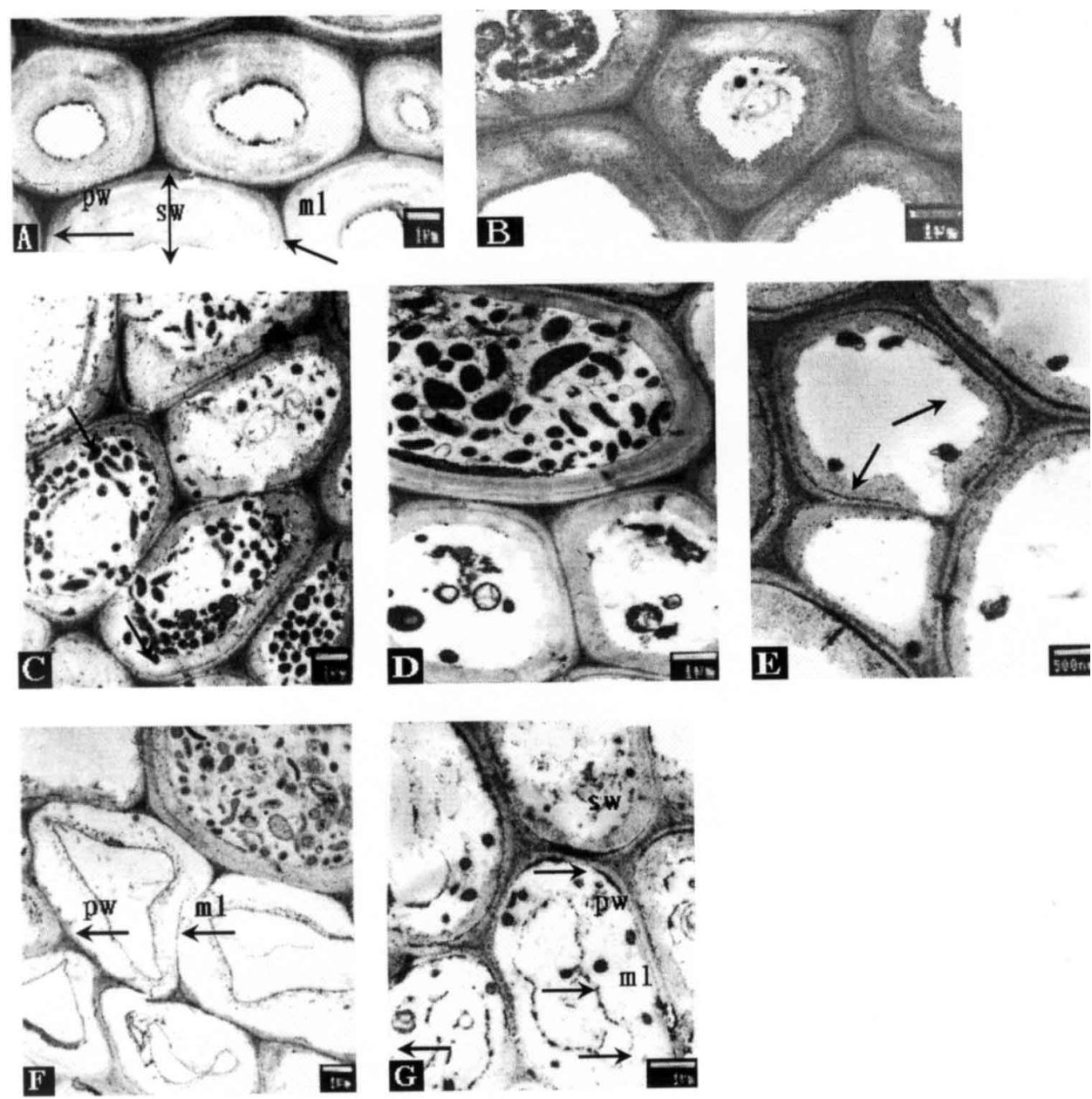

Figure 4. Sclerenchyma cells in rice straw stem. (A) Untreated cells before rumen digestion, showing the thickness of the whole cell wall and the intactness of middle lamella $(\mathrm{ml})$, primary wall $(\mathrm{pw})$ and secondary wall (sw) $(\mathrm{TEM} \times 5000)$. (B) After $48 \mathrm{~h}$ rumen digestion, few or no microorganisms appeared in the lumens and the intact cell wall of untreated stem $(\mathrm{TEM} \times 5000)$. (C) In $\mathrm{NaOH}-$ treated cells after $48 \mathrm{~h}$ rumen digestion, substantial microorganisms were visual in the lumens and the secondary wall began to be degraded (arrow) (TEM $\times 5000)$. (D) Urea-treated cells after $48 \mathrm{~h}$ rumen digestion, showing no degradation of cell wall and an uneven distribution of microorganisms $(\mathrm{TEM} \times 5000)$. After $72 \mathrm{~h}$ rumen digestion, the secondary wall of the untreated cells was sometimes lightly pitted along its edge (arrow) (E) (TEM $\times 12000)$; there merely left the middle lamella (ml) and occasional primary wall (pw) of sclerenchyma cells in the $\mathrm{NaOH}$-treated stem (F) (TEM $\times 4000)$; and there still left the secondary wall (sw) in partial cells, in addition to the middle lamella $(\mathrm{ml})$ and primary wall $(\mathrm{pw})$ of sclerenchyma cells in the urea-treated straw $(\mathrm{G})(\mathrm{TEM} \times 7500)$ 

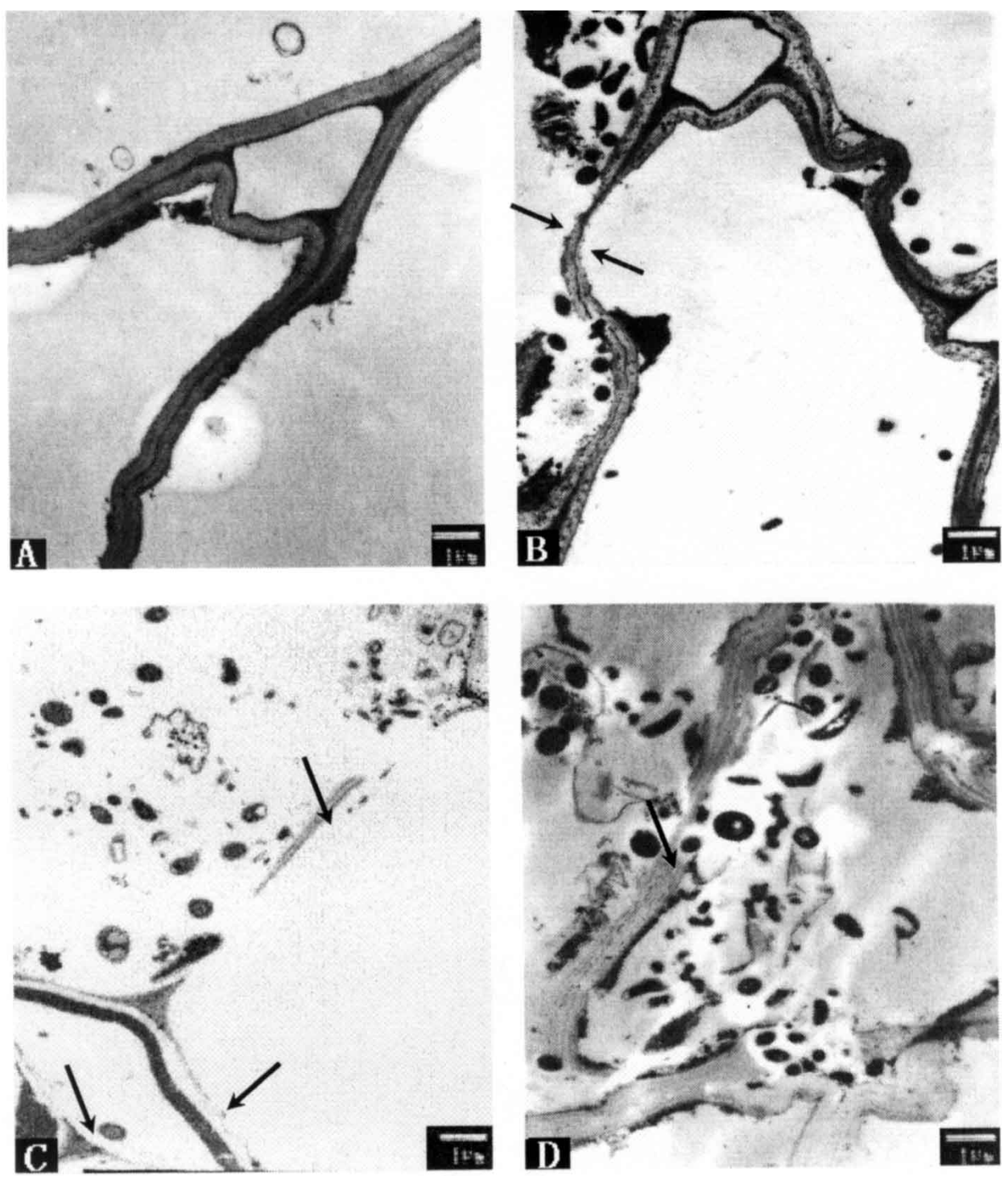

Figure 5. Ground parenchyma cell wall in rice straw stem. (A) Untreated cell wall before rumen digestion. (B) Untreated cell wall after $12 \mathrm{~h}$ rumen digestion, showing some rumen microorganisms near the cell wall and little evidence of removal in the cell wall except for in several occasional sites (arrow). (C) NaOH-treated cell wall after $12 \mathrm{~h}$ rumen digestion, showing that most components of parenchyma cell wall were removed leaving only in the middle lamella (arrow). (D) Urea-treated ground parenchyma cell wall after $12 \mathrm{~h}$ rumen digestion, showing the discontinuous degradation of cell wall (arrow) and the middle lamella in some areas $(\mathrm{TEM} \times 5000)$ 

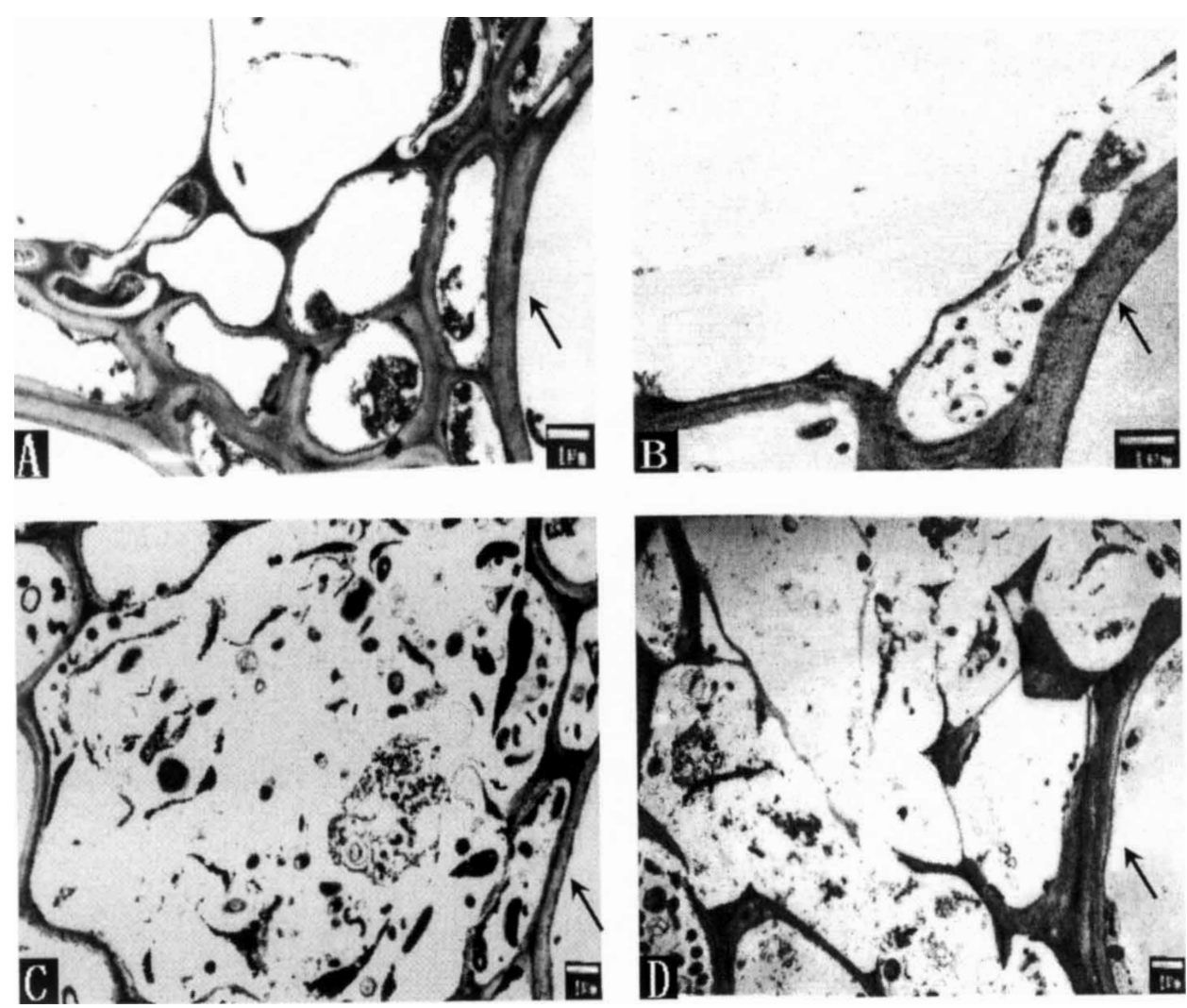

Figure 6. Phloem and xylem of small vascular tissues the in rice straw stem after $48 \mathrm{~h}$ rumen digestion. Arrow shows the undegraded xylem vessel wall. (A) Untreated phloem showing the structural integrality $(\mathrm{TEM} \times 5000)$. (B) $\mathrm{NaOH}$-treated phloem, showing that phloem was completely cleared $(\mathrm{TEM} \times 5000)$. In $\mathrm{NH}_{4} \mathrm{HCO}_{3}$-treated $(\mathrm{C})$ and urea-treated phloem (D), there were numerous cell wall residues left $(\mathrm{TEM} \times 4000)$

latter still left some secondary wall in partial sclerenchyma cells in addition to the middle lamella and primary wall (Figure 4G). The changes in $\mathrm{NH}_{4} \mathrm{HCO}_{3}-$ treated sclerenchyma cell wall were similar to those in the urea-treated (not presented).

Figure 5A showed the thin wall of parenchyma cells in untreated stem before digestion. After $12 \mathrm{~h}$ rumen incubation, the untreated ground parenchyma cells showed some microorganisms occurring near the cell wall but little evidence of removal of cell wall except for in several occasional sites (Figure 5B). In contrast, microorganisms degraded most of $\mathrm{NaOH}$-treated ground parenchyma cell wall leaving a residue of the middle lamella (Figure 5C). The parenchyma cell wall 
treated with urea was degraded discontinuously and left the middle lamella in some areas (Figure 5D), which was similar to the degradation of $\mathrm{NH}_{4} \mathrm{HCO}_{3}$-treated stem. After prolonged rumen incubation for 24 and $48 \mathrm{~h}$, all parenchyma tissues in both untreated and treated stems were extensively degraded up to complete removal (not presented), which confirmed the results obtained with SEM.

Untreated phloem cells of small vascular bundles kept intact structurally even after $48 \mathrm{~h}$ rumen digestion (Figure 6A) and presented the total loss after $72 \mathrm{~h}$ incubation (not presented). The chemical treatments were effective in improving the degradation rate of phloem. After $24 \mathrm{~h}$ rumen incubation, slight degradation occurred in $\mathrm{NaOH}$-treated phloem cells (not presented). Rumen microorganisms completely cleared phloem cells in $\mathrm{NaOH}$-treated stem (Figure 6B) and removed a most portion of phloem cells in urea- and $\mathrm{NH}_{4} \mathrm{HCO}_{3}$-treated stems with numerous cell wall residues at $48 \mathrm{~h}$ incubation (Figures 6C and 6D).

\section{DISCUSSION}

Plant tissues may be classified into two groups based on their thickness of the cell wall, and tissues with thick lignified cell wall (sclerenchyma, vascular tissue and outer wall of the epidermis) were generally lower in digestibility compared to thin cell wall type (phloem, inner wall of the epidermis and parenchyma) (Wilson, 1991). Lignified tissues are further divided into syringyl (sclerenchyma) and coniferaldehyde types (xylem); the former may be attacked more easily by microorganisms than the latter (Akin et al., 1987). The present study has demonstrated that parenchyma in RS stem is first degraded and epidermis and xylem are the least digestible tissues.

Gross examination of chemically treated and untreated stems which had undergone in sacco degradation for $72 \mathrm{~h}$, revealed that all epidermis was still intact, with little evidence of structural destruction. Besides the thick cell wall of epidermis, it may still be related to abundant silica deposited in epidermis polymerized with cuticle waxes in RS stem (Doyle et al., 1986). Some data indicated that this cuticle wax silica layer seems to be an important barrier to rumen microbial entering epidermis cell (Wilson, 1990; Nakashima et al., 1991). However, because chemical treatments have little effect on the localization of silica in straw stem, rumen microorganisms would not be expected to penetrate this barrier (Harbers et al., 1982; Zhang, 1995), which is confirmed by our observations.

Because of the different extents of lignification between the secondary and primary wall of sclerenchyma cells, the secondary wall can be relatively easily degraded and the middle lamella and primary wall are resistant to bacterial degradation (Cone and Engels, 1990; Akin et al., 1992; Engels and Schuurmans, 
1992), as shown in Figure 4. Morrison (1988) and Mulder et al. (1992) reported that alkali treatment damaged the lignin-polysaccharide bond and remove partial polysaccharides and phenolic compounds (lignin) in the secondary cell wall. In the present study, we observed that $\mathrm{NaOH}$ treatment greatly facilitated the digestion of sclerenchyma (Figure $4 \mathrm{~F}$ ), and urea and $\mathrm{NH}_{4} \mathrm{HCO}_{3}$ treatments had a slight influence on the degradation (Figure 4G), indicating that three treatments have varying effects on the degradation of sclerenchyma due to the different intensity of alkalescency.

Generally, parenchyma can be completely degraded by rumen microorganisms with the lasting digestion (Akin et al., 1992; Engels and Schuurmans, 1992). In this study, all parenchyma was completely degraded after $48 \mathrm{~h}$ digestion (Figure 3), as indicated by Akin and Burdick (1981) and Zhang (1995). However, different treatments increased the degradation rate of parenchyma to different extents (Figures 2 and 5). Rumen microbial digestion of RS stem tissues first began from the thin-wall parenchyma of stem due to the absence of cuticle wax layer and epidermis on it (Shen et al., 1999). Treatments with urea, $\mathrm{NH}_{4} \mathrm{HCO}_{3}$ and $\mathrm{NaOH}$ distorted parenchyma in different degrees (Figure 1) and made the parenchyma cell wall of stem easily ruptured, which may help rumen microbes to invade parenchyma cells easily.

There are different rates and extents of degradation between large and small vascular bundles because of their differences in location as revealed by SEM. Treatments had little effect on vascular bundles (Figure 1), in contrast with the observation by Shen et al. (1999) who reported that urea treatment cracked the wall of vascular tubes. Although the phloem tissue is, in general, readily digestible (Harbers et al., 1982), the result observed under TEM in this study illuminated the phloem of untreated stem still retained structural integrality even at $48 \mathrm{~h}$ incubation (Figure 6A), and chemical treatments seemed to help rumen bacteria to degrade the phloem of large and small vascular bundles at dissimilar digestion times (Figures 2B, 3 and 6). However, chemical treatments did not enhance the breakdown of xylem (Figures 3 and 6), which is consistent in the result of Harbers et al. (1982).

\section{CONCLUSIONS}

Of all three treatments in this study, $\mathrm{NaOH}$ treatment had the best effects on the digestion of parenchyma, sclerenchyma and phloem of vascular tissue, and the positive effects of $\mathrm{NH}_{4} \mathrm{HCO}_{3}$ treatment on these tissues basically paralleled to those of urea treatment. The improvement in digestion of histological structures was accordant entirely with the increase of in sacco degradability of RS after 
the three treatments. These results indicated that the histological methods by means of microscopical techniques such as SEM and TEM helped a direct insight into the mechanism with which chemical treatments exerted the effects on the improvement of nutritive value of RS.

\section{ACKNOWLEDGEMENTS}

The authors thank Ms. Junying Li and Mr. Liping He, the Zhejiang University Electron Microscopy Laboratory, for their assistance in the use of SEM and TEM.

\section{REFERENCES}

Akin D.E., 1989. Histological and physiological factors affection digestibility of forages. Agron. J. $81,17-25$

Akin D.E., Burdick D., 1981. Relationships of different histochemical types of lignified cell wall to forage digestibility. Crop Sci. 21, 577-581

Akin D.E., Hartley R.D., Rigsby L.L., Morrison W.H., 1992. Phenolic acids released from Bermuda grass (Cynodon dactylon) by sequential sodium hydroxide treatment in relation to biodegradation of cell types. J. Sci. Food Agr. 58, 207-214

Akin D.E., Rigsby L.I., Barton F.E.H., Gelfand P., Hammelsbach D.S., Windham W.R., 1987. Influence of delignifying agents on tissue structure in Bermuda grass stems. Food Microstr. 6, $103-113$

AOAC, 1990. Official Methods of Analysis, Association of Official Analytical Chemists. $15^{\text {th }}$ Edition. Washington, DC

Besle J.M., Cornu A., Jouany J.P., 1994. Roles of structural phenylpropanoids in forage cell wall digestion. J. Sci. Food Agr. 64, 171-190

Chaudhry A.S., 1998. Chemical and biological procedures to upgrade cereal straws for ruminants. Nutr. Abst. Rev., Ser. B 68, 793-811

Cone J.W., Engels F.M., 1990. Influence of growth temperature on anatomy and in vitro digestibility of maize tissues. J. Agr. Sci. 114, 207-212

Doyle P.T., Devendra C., Pearce G.R. (Editors), 1986. Rice Straw as a Feed for Ruminants. International Development Program of Australian Universities and Colleges, Ltd., pp. 117

Engels F.M., Schuurmans J.L.L., 1992. Relationship between structural development of cell wall and degradation of tissues in maize stems. J. Sci. Food Agr. 59, 45-51

Givens D.I., Angela R.M., 1995. The nutritional value of cereal straws for ruminants-A review. Nutr. Abstr. Rev., Ser. B 65, 319-331

Guo T.S., Sanchez M.D., Guo P.Y. (Editors), 2002. Animal Production Based on Crop Residues Chinese Experiences. FAO Animal Production and Health, FAO, Rome, Paper No. 149, pp. 1-20

Harbers L.H., Kreitner G.L., Davis G.V., 1982. Rumen digestion of ammonium hydroxide- treated wheat straw observed by scanning electron microscopy. J. Anim. Sci. 54, 1309-1319

Liu J.X., 1995. Supplementation of low quality crop residue. In: F. Dolberg, P.E. Petersen (Editors). Agricultural Science for Biodiversity and Sustainability in Developing Countries. Proceeding of a Workshop, Tune Landboskole (Denmark), pp. 165-180 
Liu J.X., Wu Y.M., Ye J.A., Dai X.M., Yao J., 1997. Recent advance on improving the efficiency of utilization of cereal straws in south China. In: Y.L. Feng (Editor). Recent Advances on Animal Nutrition in China -1996. Beijing Agricultural Press, Beijing, pp. 274-283

Morrison I.M., 1988. Influence of chemical and biological pretreatments on the degradation of lignocellulosic material by biological systems. J. Sci. Food Agr. 42, 295-304

Mulder M.M., Engels F.M., Schuurmans J.L.L., Boon J.J., 1992. In vitro digested and potassium permanganate delignified maize internode sections studied with histochemistry and pyrolysis mass spectrometry. Anim. Feed Sci. Tech. 39, 335-346

Nakashima Y., Adebowale E.A., Misawa Y., 1991. Rumen degradation of cowpea husks and rice straw: microscopic evaluation of degraded residues. Anim. Feed Sci. Tech. 35, 309-320

Ørskov E.R., Hovell F.D., Mould F., 1980. The use of the nylon bag technique for the evaluation of feedstuffs. Trop. Anim. Prod. 5, 195-213

Shen H.S., Sundstøl F., Eng E.R., Eik L.O., 1999. Studies on untreated and urea-treated rice straw from three cultivation seasons: 3. Histological investigations by light and scanning electron microscopy. Anim. Feed Sci. Tech. 80, 151-159

Van Soest P.J., Robertson J.B., Lewis B.A., 1991. Methods for dietary fibre, neutral detergent fibre, and nonstarch polysaccharides in relation to animal nutrition. J. Dairy Sci. 74, 3583-3598

Wilson J.R., 1990. Influence of plant anatomy on digestion and fibre breakdown. In: D.E. Akin, L.G. Ljungdahl, J.R. Wilson, P.J. Harris (Editors). Microbial and Plant Opportunities to Improved the Utilization of Lignocellulose by Ruminants. Elsevier, New York, pp. 99-117

Wilson J.R., 1991. Plant structures: their digestive and physical breakdown. In: Y.W. Ho, H.K. Wong, N. Abdullah, Z.A. Tajuddin (Editors). Proceedings of the $3^{\text {rd }}$ International Symposium on the Nutrition of Herbivores. Malaysia, pp. 207-216

Xu N.Y., Liu J.X., Wu Y.M., 1993. Investigation on ammonia bicarbonate treated rice straw by scanning electron microscopy. In: T.S. Guo (Editor). Proceedings of the International Conference on Increasing Livestock Production through Utilization of Local Resources. Bureau of Animal Production and Health, Ministry of Agriculture, Beijing, pp. 412-419

Zhang F.L., 1995. A study on physico-chemical and nutritional characterization of cereal straws treated by engineering methods (in Chinese). PhD. Thesis, China Agricultural University 


\section{STRESZCZENIE}

Histologiczne badania tkanek i błon komórkowych słomy ryżowej traktowanej różnymi związkami chemicznymi oraz jej rozkład w żwaczu

Słomę ryżową (SR) traktowano mocznikiem, dwuwęglanem amonu $\left(\mathrm{NH}_{4} \mathrm{HCO}_{3}\right)$ i tlenkiem sodu $(\mathrm{NaOH})$, w następstwie czego wzrósł $(\mathrm{P}<0,01)$ rozkład s.m. oznaczany in sacco, z 45,3 SR nietraktowanej do 52,5; 53,2 i 63,6\%, odpowiednio. Próby SR nietraktowanej i traktowanej były trawione w żwaczu owiec Huzhou przez 12, 24, 48 i 72 godz. celem oznaczenia rozkładu tkanek i błon komórkowych, przy zastosowaniu skaningowego (SEM) i transmisyjnego (TEM) mikroskopu elektronowego. Parenchyma była nieco uszkodzona na skutek traktowania mocznikiem lub $\mathrm{NH}_{4} \mathrm{HCO}_{3}$, a znacznie po traktowaniu $\mathrm{NaOH}$. Wpływ chemicznego traktowania na inne tkanki był mały. Wszystkie zastosowane związki przyspieszały rozkład parenchymy w 12 i 24 godz., $\mathrm{NaOH}$ - w większym stopniu. Sklerenchyma błon komórkowych RS nietraktowanej była trawiona w nieznacznym stopniu; po 72 godzinach pozostała niestrawiona część ścianki wtórnej oraz cała lamela środkowa i pierwotna ścianek. Natomiast sklerenchyma ściany komórek traktowana $\mathrm{NaOH}$ zaczynała być trawiona po 48 godzinach, a środkowa lamela i częściowo ścianka pierwotna po 72 godzinach. Wszystkie trzy sposoby traktowania słomy powodowały strawienie łyka po 48 godzinach. W 48 godzinie nie stwierdzono obecności łyka, a traktowanie w małym stopniu wpłynęło na trawienie naskórka i ksylemy tkanki naczyniowej.

Uzyskane wyniki wskazuja, że przy traktowaniu $\mathrm{RS} \mathrm{NaOH}$ otrzymuje się najlepsze wyniki dotyczące zmian struktury ździebeł słomy ryżowej oraz trawienia tkanek i błon komórkowych, i że podobne wyniki uzyskuje się przy stosowaniu $\mathrm{NH}_{4} \mathrm{HCO}_{3}$. Poprawa trawienia histologicznych struktur jest zgodna ze zwiększeniem rozkładu in sacco RS po traktowaniu różnymi związkami chemicznymi. Można zasugerować, że metody histologiczne przy użyciu technik mikroskopowych, takich jak SEM i TEM, umożliwiają bezpośredni wgląd w mechanizmy chemicznego traktowania wywierającego wpływ na polepszenie wartości pokarmowej słomy ryżowej. 